\title{
Thromboembolic events in cancer patients on active treatment with cisplatin-based chemotherapy: another look!
}

\author{
Hikmat Abdel-Razeq ${ }^{1 *}$ (D), Asem Mansour², Hazem Abdulelah', Anas Al-Shwayat ${ }^{1}$, Mohammad Makoseh', \\ Mohammad Ibrahim', Mahmoud Abunasser ${ }^{1}$, Dalia Rimawi ${ }^{3}$, Abeer Al-Rabaiah", Rozan Alfar ${ }^{1}$, Alaa' Abufara', \\ Alaa Ibrahim², Anas Bawaliz ${ }^{1}$ and Yousef Ismael ${ }^{5}$
}

\begin{abstract}
Background: The risk of thromboembolic events is higher among cancer patients, especially in patients undergoing chemotherapy. Cisplatin-based regimens claim to be associated with a very high thromboembolic rate. In this study, we report on our own experience with thrombosis among patients on active cisplatin-based chemotherapy.

Methods: Medical records and hospital databases were searched for all the patients treated with any cisplatin-based regimen for any kind of cancer. Thrombosis was considered cisplatin-related if diagnosed any time after the first dose and up to 4 weeks after the last. The Khorana risk assessment model was performed in all cases.

Results: A total of 1677 patients (65.5\% males, median age: 50 years) treated with cisplatin-based regimens were identified. Head and neck (22.9\%), lung (22.2\%), lymphoma and gastric (11.4\% each) were the most common primary tumors. Thromboembolic events were reported in 110 (6.6\%); the highest was in patients with gastric cancer (20.9\%) and the lowest in patients with head and neck cancers (2.3\%) and lymphoma (1.6\%). Thrombosis included deep vein thrombosis (DVT) in 69 (62.7\%), pulmonary embolism (PE) in 18 (16.9\%) and arterial thrombosis in 17 (15.6\%). A majority (51.1\%) of the patients had stage IV disease and only 16\% had stage I or II.

In a multivariate analysis, significantly higher rates of thrombosis were associated with gastric as the primary tumor, advanced-stage disease, female sex but not age, and the Khorana risk score or type of cisplatin regimen. While the presence of CVC was significantly associated with the risk of thrombosis $(p<0.0001)$ in the univariate analysis, and such significance was lost in the multivariate analysis (odds ratio, 1.098; 95\% Cl, 0.603-1.999, $p=0.7599$ ).
\end{abstract}

Conclusions: Thromboembolic events in cancer patients on active cisplatin-based chemotherapy were commonly encountered. Gastric cancer, regardless of other clinical variables, was associated with the highest risk.

Keywords: Cisplatin, Chemotherapy, Thrombosis, Cancer

\section{Background}

Venous thromboembolism (VTE) and, to a lesser extent, arterial thrombosis are common complications encountered in patients with cancer during the course of their treatment and follow-up [1,2].

Much of this high risk is attributed to the cancer itself or its therapy. However, patient-related factors such as age,

\footnotetext{
* Correspondence: habdelrazeq@khcc.jo

${ }^{1}$ Department of Internal Medicine, King Hussein Cancer Center, 202 Queen

Rania Al-Abdulla St., P.O. Box 1269, Amman 11941, Jordan

Full list of author information is available at the end of the article
}

performance status, body mass index and underlying comorbidities are also important factors [3, 4].

Thromboembolic events are one of the leading causes of death in patients with cancer [5]. Many studies show that the survival of cancer patients with thrombosis is significantly lower than those without [6-8].

Cisplatin is an old chemotherapeutic drug that was licensed in 1978 and is now listed on the World Health Organization's list of essential medicines. It is widely used, alone or in combination, to treat a number of cancers, including testicular, ovarian, cervical, bladder, head and neck, lung, esophageal and gastric cancers $[9,10]$. 
Cisplatin is well known for its vascular and thrombotic complications, including both venous and arterial thrombosis [11-13]. In one study, researchers at Memorial Sloan-Kettering Cancer Center (MSKCC) and Michigan State University reported a thrombosis rate of $18.1 \%$ among 932 patients treated with cisplatin-based regimens for various kinds of cancers. All had their thromboembolic events while on active cisplatin therapy or within 4 weeks of the last dose. Deep vein thrombosis (DVT) and/or pulmonary embolism (PE) accounted for almost $90 \%$ of the events [14]. More recently, a higher risk of VTE [crude relative risk of 2.8 (95\% CI, 1.4-4.2)] was also reported in a group of 200 patients with various malignancies undergoing treatment with cisplatin-based chemotherapy compared to 200 others who received non-cisplatin-based chemotherapy [15]. A meta-analysis that involved 8216 patients treated with different chemotherapy regimens for various advanced solid tumors from 38 randomized controlled trials was recently reported. Patients receiving cisplatin-based chemotherapy had a significantly increased risk of VTEs (RR, 1.67; 95\% CI, 1.25 to 2.23; $P=0.01)$ [16].

Given the variation in the reported thromboembolic rates among such patients, this study highlights the observed thrombosis rate in real daily clinical practice. Factors that help predict the occurrence of thrombosis were also studied. Following this analysis, it was hypothesized that particular group(s) of patients with specific clinical features and particular primary tumors treated with cisplatin-based regimen could be identified as high risk for VTE to justify prophylaxis, even in the ambulatory setting. The results of this study could help design clinical trials addressing preventive measures for a subgroup of patients with the highest risk.

\section{Methods}

Medical records and the hospital database were searched for patients treated with any cisplatin-based regimen for any kind of cancer. All adult patients ( $\geq 18$ years old) that were treated between January 2007 and December 2015 and had at least 4 weeks of follow-up after their last cisplatin dose were included.

The patients' medical records and imaging reports were searched for a diagnosis of venous or arterial thrombosis. To avoid any missing events, we also searched the pharmacy database for any anticoagulant therapy for all the patients who received cisplatin-based chemotherapy during this period.

The presence of central venous catheter (CVC) and other thrombotic risk factors used to calculate the Khorana risk score were collected, and such risk factors included hemoglobin level, platelet and WBC counts, primary cancer site, disease stage, and body mass index (BMI) [17]. Patients were then grouped into three risk categories, including high, intermediate and low risk, as shown in Table 1. Thrombosis was considered cisplatinrelated if it was diagnosed any time after the first dose and up to 4 weeks after the last. All DVT was diagnosed by Doppler ultrasound, while all the PE were diagnosed by $\mathrm{CT}$ angiogram. This study was approved by our institutional review board.

\section{Statistical analysis}

The primary objective of this study was to determine the overall incidence and characteristics of thrombosis in adult patients receiving cisplatin-based chemotherapy with or without radiation therapy. The secondary objectives were to analyze the importance of the patients' tumor and treatment characteristics in predicting the occurrence of thrombosis.

The association between such variables and the development of thromboembolic events during the defined treatment period was evaluated using the $X^{2}$ test for categorical variables and the Wilcoxon rank sum test for continuous variables. The variables found to be significant $(p<0.05)$ by the univariate analysis were subsequently entered into a multivariate logistic regression model. Following this analysis, it was hypothesized that particular group(s) of patients with specific clinical features and particular primary tumors treated with cisplatin-based regimen could be identified as high risk for VTE to justify prophylaxis, even in the ambulatory setting.

\section{Results}

During the study period, 1677 patients received at least one cycle of cisplatin-based regimen and were included in this study. The median age was 50 years (range: 1883 years), and 1099 (65.5\%) were male. The most common primary tumors encountered were head and neck (22.9\%), lung (22.2\%), lymphoma (11.4\%), gastric (11.4\%), and testicular (8.4\%). A majority of the patients had advanced-

Table 1 Khorana Risk Assessment Model

\begin{tabular}{ll}
\hline Patient characteristic & Risk Score \\
\hline $\begin{array}{l}\text { 1. Site of cancer } \\
\text { - Very high risk (stomach, pancreas) }\end{array}$ & 2 \\
- High risk & 1 \\
$\quad$ (Lung, Lymphoma, Gynecologic, bladder, testicular) & \\
2. Prechemotherapy platelet count $350 \times 10^{9} / \mathrm{L}$ or more & 1 \\
$\begin{array}{l}\text { 3. Hemoglobin level less than } 100 \mathrm{~g} / \mathrm{L} \text { or use of red cell } \\
\text { growth factors }\end{array}$ & 1 \\
$\begin{array}{l}\text { 4. Prechemotherapy leukocyte count more than } 11 \times 10^{9} / \mathrm{L} \\
\text { 5. BMI: } 35 \text { kg/m }{ }^{2} \text { or more }\end{array}$ & 1 \\
\hline Three Risk Groups: & 1 \\
- Low Risk 0 & \\
- Intermediate Risk 1-2 & \\
- High Risk $\geq 3$ &
\end{tabular}


stage disease at the time of chemotherapy administration, and 858 (51.2\%) patients were stage IV and 487 (29.0\%) patients had stage III disease. Chemotherapy was delivered through a central venous catheter (CVC) in 303 (18.1\%) patients as shown in Table 2 . None of the patients had any form of thromboprophylaxis while in ambulatory settings.

Thromboembolic events were reported in $110(6.6 \%)$ patients; 96 (5.7\%) were venous thrombosis in the form of DVT and/or PE, and $14(0.83 \%)$ had arterial thrombosis. The thrombosis rate was highest among patients with gastric cancer; it was reported in 40 (20.9\%) of 191 patients compared to 70 (4.7\%) of 1486 patients with other tumor types, $p<0.0001$. The thromboembolic rates were particularly low among the patients with lymphoma (1.6\%), head and neck (2.3\%) and testicular cancers (2.8\%).

Table 2 Patients Characteristics ( $n=1677$ )

\begin{tabular}{|c|c|c|c|}
\hline Characteristic & No. of Patients & & Percentage \\
\hline \multicolumn{4}{|l|}{ Age (Years) } \\
\hline Median & & 50 & \\
\hline Range & & $18-83$ & \\
\hline \multicolumn{4}{|l|}{ Sex } \\
\hline Male & 1099 & & 65.5 \\
\hline Females & 578 & & 34.5 \\
\hline \multicolumn{4}{|l|}{ Primary Tumor } \\
\hline Head and Neck & 384 & & 22.9 \\
\hline Lung & 373 & & 22.2 \\
\hline Gastric & 191 & & 11.4 \\
\hline Lymphoma & 191 & & 11.4 \\
\hline Cervical & 121 & & 7.2 \\
\hline Testicular & 104 & & 6.2 \\
\hline Bladder & 77 & & 4.6 \\
\hline Sarcoma & 45 & & 2.7 \\
\hline Esophageal & 33 & & 2.0 \\
\hline Others & 158 & & 9.4 \\
\hline \multicolumn{4}{|l|}{ Khorana Risk Score } \\
\hline Low & 350 & & 20.9 \\
\hline Intermediate & 1075 & & 64.1 \\
\hline High & 252 & & 15.0 \\
\hline \multicolumn{4}{|c|}{ Central Venous Catheter } \\
\hline Present & 303 & & $18.1 \%$ \\
\hline Absent & 1374 & & $81.9 \%$ \\
\hline \multicolumn{4}{|l|}{ Disease Stage } \\
\hline । & 56 & & 3.3 \\
\hline$\|$ & 213 & & 12.7 \\
\hline III & 487 & & 29.0 \\
\hline IV & 857 & & 51.1 \\
\hline Unstageable/Unknown & 64 & & 3.8 \\
\hline
\end{tabular}

The thrombosis rate was also studied in relation to the Khorana risk score. Patients with a high-risk score had higher rates of thromboembolic events, which were reported in 33 (13.1\%) of 252 such patients compared to $77(5.4 \%)$ of all the other patients with an intermediate or low-risk score, $p<0.0001$, as shown in Table 3 .

We also studied the effect of a combination chemotherapy regimen on the incidence of thrombosis. This rate was highest $(30.0 \%)$ among a small group of 30 patients treated with ECF (epirubicin, cisplatin and fluorouracil (5-FU)); all of these patients had gastric cancer. The rate of thrombosis was $12.7 \%$ in the 245 treated with cisplatin, docetaxel and 5-FU, was only $2.1 \%$ among the 145 patients treated with cisplatin and etoposide and was $4.3 \%$ among the 116 patients treated with the BEP

Table 3 Thromboembolic events for the whole group

\begin{tabular}{|c|c|c|c|c|c|}
\hline & \multicolumn{2}{|c|}{$\begin{array}{l}\text { Whole Group } \\
\text { (1677) }\end{array}$} & \multicolumn{3}{|c|}{$\begin{array}{l}\text { Patients with thrombosis } \\
(110)\end{array}$} \\
\hline & Number & $\%$ & Number & $\%$ & $p$-value \\
\hline \multicolumn{6}{|l|}{ Sex } \\
\hline Male & 1099 & 65.5 & 58 & 5.3 & \multirow[t]{2}{*}{0.003} \\
\hline Female & 578 & 34.5 & 52 & 9.0 & \\
\hline \multicolumn{6}{|l|}{ Age (Years) } \\
\hline Missed & 1 & & & & \multirow[t]{3}{*}{0.6445} \\
\hline$\leq 60$ & 1276 & 76.1 & 81 & 6.3 & \\
\hline$>60$ & 400 & 23.9 & 28 & 7.0 & \\
\hline \multicolumn{6}{|l|}{ Primary Tumor } \\
\hline Head and Neck & 384 & 22.9 & 9 & 2.3 & \multirow[t]{10}{*}{$<0.0001$} \\
\hline Lung & 373 & 22.2 & 25 & 6.7 & \\
\hline Gastric & 191 & 11.4 & 40 & 20.9 & \\
\hline Lymphoma & 191 & 11.4 & 3 & 1.6 & \\
\hline Testicular & 104 & 6.2 & 4 & 3.8 & \\
\hline Cervical & 121 & 7.2 & 7 & 5.8 & \\
\hline Bladder & 77 & 4.6 & 3 & 3.9 & \\
\hline Sarcoma & 45 & 2.7 & 3 & 6.7 & \\
\hline Esophageal & 33 & 2.0 & 6 & 18.2 & \\
\hline Others & 158 & 9.4 & 10 & 6.3 & \\
\hline \multicolumn{6}{|l|}{ Khorana Risk Score } \\
\hline Low risk & 350 & 20.9 & 16 & 4.6 & \multirow[t]{3}{*}{$<0.0001$} \\
\hline Intermediate risk & 1075 & 64.1 & 61 & 5.7 & \\
\hline High risk & 252 & 15.0 & 33 & 13.1 & \\
\hline \multicolumn{6}{|l|}{ Disease Stage } \\
\hline I & 56 & 3.3 & 3 & 5.4 & \multirow[t]{5}{*}{0.0038} \\
\hline$\|$ & 213 & 12.7 & 8 & 3.8 & \\
\hline III & 487 & 29 & 20 & 4.1 & \\
\hline IV & 857 & 51.1 & 76 & 8.9 & \\
\hline Unstageable/Unknown & 64 & 3.8 & 3 & 4.7 & \\
\hline
\end{tabular}


(bleomycin, etoposide and cisplatin) regimen or cisplatin and radiation therapy. Table 4 shows the chemotherapy regimens and corresponding thromboembolic events.

To further address the effect of the chosen combination chemotherapy regimen in relation to a particular disease, we studied the three most commonly utilized regimens, including Cisplatin-Radiation (299 patients), CisplatinDocetaxel-5FU (245 patients) and Cisplatin-Docetaxel (193 patients). While none of the 95 patients with head and neck cancers treated with (Cisplatin-Docetaxel-5FU) had any thromboembolic events, 28 (20.6\%) of the 136 patients with gastric cancer and $3(42.9 \%)$ of the 7 patients with esophageal cancers treated with the same regimen had thrombosis, $p<0.0001$. Further details are shown in Table 5 .

We further analyzed the 191 gastric patients and studied the rate of thrombosis in relation to many other variables, including the chosen combination chemotherapy, the disease stage, the Khorana risk score and age. None of those clinical variables had a significant impact on the rates of thromboembolic events, as shown in Table 6.

To further address the association of the baseline and treatment variables with the development of thrombosis, a univariate analysis was conducted. Sex, the Khorana risk score, the presence of central venous catheter $(\mathrm{CVC})$, and the primary tumor site and stage were all associated with a significantly higher rate of thrombosis as shown in Table 7.

The significant variables in the univariate analysis were subsequently entered into a multivariate logistic regression model. In the multivariate analysis, only sex (odds ratio,

Table 4 Thromboembolic events according to chemotherapy regimen

\begin{tabular}{llll}
\hline Chemotherapy & $\begin{array}{l}\text { Number } \\
\text { of Patients }\end{array}$ & \multicolumn{2}{l}{ Thromboembolic Events } \\
\cline { 4 - 5 } & & (n) & $\%$ \\
\hline Cisplatin-XRT & 299 & 13 & 4.3 \\
Cisplatin-Docetaxel-5FU & 245 & 31 & 12.7 \\
Cisplatin-Docetaxel & 194 & 13 & 6.7 \\
DHAP & 180 & 3 & 1.7 \\
Cisplatin-Etoposide & 145 & 3 & 2.1 \\
Cisplatin-5FU & 120 & 9 & 7.5 \\
BEP & 116 & 5 & 4.3 \\
Cisplatin-Gemcitabine & 95 & 9 & 9.5 \\
Cisplatin-Doxorubicin & 42 & 3 & 7.1 \\
Cisplatin-Etoposide-XRT & 38 & 4 & 10.5 \\
ECF & 30 & 9 & 30.0 \\
Cisplatin-Pemetrexed & 19 & 3 & 15.8 \\
Others & 154 & 5 & 3.2
\end{tabular}

5-FU 5-Flurouracil, DHAP Dexamethasone, High-dose Ara-C and Cisplatin; BEP Bleomycin, Etoposide and Cisplatin, ECF Epirubicin Cisplatin and 5-Flurouracil, XRT Radiation therapy
Table 5 Thromboembolic events according to Cisplatin-based chemotherapy regimen

\begin{tabular}{|c|c|c|c|c|c|}
\hline \multirow{2}{*}{$\begin{array}{l}\text { Chemotherapy } \\
\text { Regimen }\end{array}$} & \multicolumn{2}{|c|}{ Patients } & \multicolumn{2}{|c|}{ Thromboembolic Events } & \multirow[t]{2}{*}{$p$-value } \\
\hline & $(n)$ & $(\%)$ & (n) & $(\%)$ & \\
\hline \multicolumn{6}{|c|}{ Cisplatin-Docetaxel-5FU } \\
\hline Head and Neck & 95 & 38.8 & 0 & 0 & \multirow[t]{5}{*}{$<0.000$} \\
\hline Gastric & 136 & 55.5 & 28 & 20.6 & \\
\hline Esophageal & 7 & 2.9 & 3 & 42.9 & \\
\hline Others & 7 & 2.9 & 0 & 0 & \\
\hline Total & 245 & & 31 & 12.7 & \\
\hline \multicolumn{6}{|l|}{ Cisplatin-XRT } \\
\hline Cervical & 101 & 33.8 & 7 & 6.9 & \multirow[t]{4}{*}{0.2166} \\
\hline Head and Neck & 184 & 61.5 & 5 & 2.7 & \\
\hline Others & 14 & 4.7 & 1 & 7.1 & \\
\hline Total & 299 & & 13 & 4.3 & \\
\hline \multicolumn{6}{|c|}{ Cisplatin-Docetaxel } \\
\hline Lung & 181 & 93.3 & 12 & 6.6 & \multirow[t]{3}{*}{0.9999} \\
\hline Others & 13 & 6.7 & 1 & 7.7 & \\
\hline Total & 194 & & 13 & 6.7 & \\
\hline
\end{tabular}

5FU 5-Flurouracil, XRT Radiation therapy

1.732; 95\% CI, 1.152-2.605, $p=0.0083$ ), gastric cancer as the primary site (odds ratio, 3.377; 95\% CI, 1.759-6.483, $p=0.0003$ ) and disease stage (odds ratio, $1.665 ; 95 \% \mathrm{CI}$, $1.054-2.63, p=0.0289$ ) were significantly associated with thromboembolic events as shown in Table 8. In addition,

Table 6 Thromboembolic events in patients with Gastric cancer

\begin{tabular}{|c|c|c|c|c|}
\hline \multirow[t]{2}{*}{ Clinical Variables } & \multirow[t]{2}{*}{$\begin{array}{l}\text { Number of } \\
\text { Patients }\end{array}$} & \multicolumn{2}{|c|}{$\begin{array}{l}\text { Thromboembolic } \\
\text { Events }\end{array}$} & \multirow[t]{2}{*}{$p$-Value } \\
\hline & & $(\mathrm{n})$ & (\%) & \\
\hline \multicolumn{5}{|l|}{ Chemotherapy Regimen } \\
\hline ECF & 26 & 8 & 30.8 & \multirow[t]{4}{*}{0.5982} \\
\hline Cisplatin-Docetaxel-5FU & 137 & 28 & 20.4 & \\
\hline Cisplatin-5FU & 20 & 4 & 20 & \\
\hline Others & 8 & 0 & 0 & \\
\hline \multicolumn{5}{|l|}{ Disease Stage } \\
\hline Early Stage & 35 & 11 & 31.4 & \multirow[t]{2}{*}{0.0916} \\
\hline Metastatic & 156 & 29 & 18.5 & \\
\hline \multicolumn{5}{|l|}{ Khorana Risk Score } \\
\hline Low $^{a}$ & 1 & 1 & & \multirow[t]{3}{*}{0.5331} \\
\hline Intermediate & 101 & 19 & 18.8 & \\
\hline High & 89 & 20 & 22.5 & \\
\hline \multicolumn{5}{|l|}{ Age (years) } \\
\hline Missed & 1 & & & \multirow[t]{3}{*}{0.8647} \\
\hline$<50$ & 90 & 18 & 18.5 & \\
\hline$\geq 50$ & 100 & 21 & 23.5 & \\
\hline
\end{tabular}

ECF Epirubicin, Cisplatin and 5-Flurouracil, 5-FU 5-Flurouracil ${ }^{\text {a }}$ Only one patient and had thrombosis 
Table 7 Univariate Analysis for thromboembolic events

\begin{tabular}{|c|c|c|c|c|}
\hline Factors & & $\begin{array}{l}\text { Number of } \\
\text { Patients }\end{array}$ & $\begin{array}{l}\text { Thromboembolic } \\
\text { Events } \\
110(6.6 \%)\end{array}$ & $P$-value \\
\hline \multirow[t]{2}{*}{ Age } & $\leq 60$ & $\begin{array}{l}1276 \\
(76.1 \%)\end{array}$ & 81 (6.3\%) & 0.6445 \\
\hline & $>60$ & $\begin{array}{l}401 \\
(23.9 \%)\end{array}$ & $29(7.2 \%)$ & \\
\hline \multirow[t]{2}{*}{ Gender } & Female & $\begin{array}{l}578 \\
(34.5 \%)\end{array}$ & $52(9.0 \%)$ & 0.003 \\
\hline & Male & 1099 (65.5\%) & $58(5.3 \%)$ & \\
\hline \multirow[t]{2}{*}{ Khorana risk } & High & $\begin{array}{l}252 \\
(15.0 \%)\end{array}$ & $33(13.1 \%)$ & $<0.0001$ \\
\hline & Others & $\begin{array}{l}1423 \\
(85.0 \%)\end{array}$ & 77 (5.4\%) & \\
\hline \multirow{2}{*}{$\begin{array}{l}\text { Central venous } \\
\text { catheter }\end{array}$} & No & 1374 (81.9\%) & $70(5.1 \%)$ & $<0.0001$ \\
\hline & Yes & $\begin{array}{l}303 \\
(18.1 \%)\end{array}$ & 40 (13.2\%) & \\
\hline \multirow[t]{2}{*}{ Primary Tumor } & Gastric & $\begin{array}{l}191 \\
(11.4 \%)\end{array}$ & 40 (20.9\%) & $<0.0001$ \\
\hline & Other & $\begin{array}{l}1486 \\
(88.6 \%)\end{array}$ & $70(4.7 \%)$ & \\
\hline \multirow[t]{2}{*}{ Stage } & IV & $\begin{array}{l}857 \\
(51.1 \%)\end{array}$ & 76 (8.9\%) & $<0.0001$ \\
\hline & Early stage & 756 (45.1\%) & $31(4.1 \%)$ & \\
\hline
\end{tabular}

the presence of CVC was significantly associated with risk of thrombosis $(p<0.0001)$ in the univariate analysis, and this significance was lost in the multivariate analysis (odds ratio, 1.098; 95\% CI, 0.603-1.999, $p=0.7599$ ).

\section{Discussion}

The association of cisplatin with thrombosis is wellknown. However, its pathogenesis remains unclear. Endothelial cell damage, as revealed by the increased plasma levels of the Von Willebrand factor during chemotherapy, is believed to be a major contributing factor [18]. Platelet activation and the up-regulation of prothrombotic factors are also implicated in cisplatinassociated thrombosis [19-21].

Table 8 Multivariate Analysis for thromboembolic events

\begin{tabular}{llll}
\hline Factor & $\begin{array}{l}\text { Odds } \\
\text { Ratio }\end{array}$ & $\begin{array}{l}\text { 95\% Confidence } \\
\text { Limits }\end{array}$ & P-value \\
\hline $\begin{array}{l}\text { Primary Tumor } \\
\text { (Gastric vs. Others) }\end{array}$ & 3.377 & $1.759-6.483$ & 0.0003 \\
$\begin{array}{l}\text { Gender } \\
\text { (Female vs. Male) }\end{array}$ & 1.732 & $1.152-2.605$ & 0.0083 \\
$\begin{array}{l}\text { Khorana risk group } \\
\text { (High vs. Others) }\end{array}$ & 1.387 & $0.842-2.285$ & 0.1992 \\
$\begin{array}{l}\text { Central Venous Catheter } \\
\text { (Presence vs. Absence) }\end{array}$ & 1.098 & $0.603-1.999$ & 0.7599 \\
$\begin{array}{l}\text { Stage } \\
\text { (IV vs. Early stage) }\end{array}$ & 1.665 & $1.054-2.63$ & 0.0289 \\
\hline
\end{tabular}

In addition to venous thrombosis, arterial thrombosis is also well-described. In one study, 25 cases of myocardial infarction (MI) and cerebrovascular accidents (CVA) were reported among a group of young patients treated with cisplatin-based regimens for testicular cancer. None of these patients had known risk factors and none had atherosclerotic features [22].

Given the high recurrence rates [23], poor quality of life, and worse overall survival associated with thrombosis in cancer patients $[6-8,24]$, antithrombotic prophylaxis is widely practiced. Much of the emphasis is given to patients admitted for medical illnesses or surgical procedures. Such practice was endorsed by many international clinical practice guidelines, including the American Society of Clinical Oncology (ASCO) and the National Comprehensive Cancer Network (NCCN) $[25,26]$.

However, many recent studies addressing thrombosis in cancer patients show that a significant portion of these patients had thrombosis while in an ambulatory setting and were never admitted at the time or just prior to their thrombotic events [27]. Many factors contributed to these findings, and routine oncology practice has recently shifted away from the inpatient setting to the ambulatory one. Additionally, we tend to offer chemotherapy to much older and sicker patients. Routine thrombotic prophylaxis for such ambulatory cancer patients is not endorsed by any of the published guidelines.

Several efforts have been made to address the issue of prophylaxis among ambulatory cancer patients on active chemotherapy. Khorana, et al. suggested a risk assessment model that assigns these patients into three risk levels, including high, intermediate, and low [17]. Despite its simplicity and the availability of the data needed to calculate the risk of VTE, this model failed to gain popularity in clinical practice, and several studies show that it can be only applied to a small portion of such ambulatory patients [28]. Additionally, although the Khorana score, detailed in Table 1, considered gastric cancer as a high-risk type (score of 2), it did not consider the type of chemotherapy offered as a risk category.

Enrolling high-risk patients in clinical trials to test the value of thromboembolic prophylaxis in a wide range of cancer patients was another promising approach. However, due to a higher risk of bleeding and despite the associated benefit in lowering the thrombosis rate, this approach also failed to show a significant overall clinical benefit [29, 30].

A third approach was offering VTE prophylaxis to a particular high-risk group of patients with a specific diagnosis, such as advanced pancreatic cancer, undergoing active chemotherapy. The benefit of this approach was also offset by the high rate of bleeding [31, 32]. Another approach, 
similar to the one under discussion in this study, is to link a specific kind of chemotherapy and thrombosis risk. Cisplatin, as discussed earlier, is a good example.

Our thrombosis rate was lower than the $18 \%$ reported by the MSKCC group [14]. Many factors could have contributed to this lower rate, including a lower riskpatient population enrolled and different diagnostic methods. However, clinically important observations were noted and deserve discussion. In our study, we identified a specific subgroup of cancer patients treated with cisplatin-based chemotherapy with a real high risk for thrombosis. Patients with gastric cancer had a significantly higher rate of thrombosis, which was $20.9 \%$ compared to $4.7 \%$ among other patients receiving a similar cisplatin-based chemotherapy regimen. This high rate of thrombosis among patients with gastric cancer was high regardless of their age, stage, Khorana risk score, or the combination chemotherapy regimen used as shown in Table 6.

Given this relatively high rate, we proposed here that such patients could be selected into a randomized clinical trial to test the value of thrombotic prophylaxis among them, and most of them were usually treated with chemotherapy in the ambulatory setting without prophylaxis.

Thromboembolic prophylaxis in particular disease entities undergoing specific combinations of chemotherapy is routinely practiced in diseases, such as multiple myeloma (MM). We now have strong evidence and clear guidelines to offer antithrombotic prophylaxis when these patients are treated with immune modulators (thalidomide and lenalidomide) when combined with dexamethasone $[25,26]$.

We hope that future clinical research will lead to clear guidelines recommending antithrombotic prophylaxis in high-risk cancer patients, such as those with gastric cancer treated with a cisplatin-based regimen, even when done in ambulatory settings similar to what we routinely do with MM patients.

\section{Conclusions}

Thromboembolic events among cancer patients on active cisplatin-based chemotherapy are relatively common. The highest thrombosis rates were encountered in patients with gastric cancer regardless of other clinical variables. Prospective randomized trials are needed to study the value of VTE prophylaxis in such high-risk patients.

\section{Abbreviations}

5-FU: Fluorouracil; ASCO: American Society of Clinical Oncology; BEP: Bleomycin, Etoposide and Cisplatin; BMI: Body mass index; CVA: Cerebrovascular accidents; CVC: Central venous catheter; DHAP: Dexamethasone, High-dose Ara-C and Cisplatin; DVT: Deep vein thrombosis; ECF: Epirubicin, Cisplatin and Fluorouracil; MI: Myocardial infarction; MM: Multiple myeloma; NCCN: National Comprehensive Cancer Network; PE: Pulmonary embolism; VTE: Venous thromboembolism: XRT: Radiation therapy

\section{Acknowledgements}

The authors would like to thank Mrs. Alice Haddadin, Haifa Al-Ahmad and Laila Alqatu for the help in preparing this manuscript.

Funding

None.

Availability of data and materials

Please contact the authors for data requests.

\section{Authors' contributions}

HA: Designed and coordinated the study, performed the data analysis and drafted and wrote the final version of the manuscript. AM: Helped in the study design, data analysis and writing the final draft. $\mathrm{HA}, \mathrm{AS}, \mathrm{MM}, \mathrm{Ml}, \mathrm{MA}$, $A R, R A, A A, A l, A B, Y l:$ Data collection, analysis and interpretation. DR: Performed the statistical analysis. All the authors read and approved the final manuscript.

Ethics approval and consent to participate

The study was approved by our Institutional Review Board and consent was waived.

Consent for publication

Not applicable.

Competing interests

The authors declare that they have no competing interests.

\section{Publisher's Note}

Springer Nature remains neutral with regard to jurisdictional claims in published maps and institutional affiliations.

\section{Author details}

'Department of Internal Medicine, King Hussein Cancer Center, 202 Queen Rania Al-Abdulla St., P.O. Box 1269, Amman 11941, Jordan. ${ }^{2}$ Radiology, King Hussein Cancer Center, Amman, Jordan. ${ }^{3}$ Scientific and Reseaerch Office, King Hussein Cancer Center, Amman, Jordan. ${ }^{4}$ Pharmacy, King Hussein Cancer Center, Amman, Jordan. ${ }^{5}$ Radiation Oncology, King Hussein Cancer Center, Amman, Jordan.

Received: 6 September 2017 Accepted: 2 January 2018

Published online: 01 March 2018

References

1. Timp JF, Braekkan SK, Versteeg HH, Cannegieter SC. Epidemiology of cancer-associated venous thrombosis. Blood. 2013;122(10):1712-23.

2. Khorana AA, Francis CW, Culakova E, Kuderer NM, Lyman GH. Frequency, risk factors, and trends for venous thromboembolism among hospitalized cancer patients. Cancer. 2007;110(10):2339-46.

3. Falanga $A$, Marchetti $M$, Vignoli A. Coagulation and cancer: biological and clinical aspects. J Thromb Haemost. 2013;11(2):223-33.

4. Khorana AA. Risk assessment and prophylaxis for VTE in cancer patients. J Natl Compr Cancer Netw. 2011;9(7):789-97.

5. Khorana AA, Francis CW, Culakova E, Kuderer NM, Lyman GH. Thromboembolism is a leading cause of death in cancer patients receiving outpatient chemotherapy. J Thromb Haemost. 2007;5:632-4.

6. Agnelli G, Verso M, Mandala M, Gallus S, Cimminiello C, Apolone G, et al. A prospective study on survival in cancer patients with and without venous thromboembolism. Intern Emerg Med. 2014;9(5):559-67.

7. Sørensen HT, Mellemkjaer L, Olsen JH, Baron JA. Prognosis of cancers associated with venous thromboembolism. N Engl J Med. 2000:343(25):1846-50.

8. Mandalà M, Reni M, Cascinu S, Barni S, Floriani I, Cereda S, et al. Venous thromboembolism predicts poor prognosis in irresectable pancreatic cancer patients. Ann Oncol. 2007;18(10):1660-5.

9. Fischer J, Ganellin CR. Analogue-based drug discovery. John Wiley \& Sons. 2006. p. 513. ISBN 9783527607495. 
10. WHO Model List of Essential Medicines (19th List). Available at: http://www. who.int/medicines/publications/essentialmedicines/EML2015_8-May-15.pdf. Accessed 01 May 2017.

11. Anders JC, Grigsby PW, Singh AK. Cisplatin chemotherapy (without erythropoietin) and risk of life-threatening thromboembolic events in carcinoma of the uterine cervix: the tip of the iceberg? A review of the literature. Radiat Oncol. 2006;1:14.

12. Czaykowski PM, Moore MJ, Tannock IF. High risk of vascular events in patients with urothelial transitional cell carcinoma treated with cisplatin based chemotherapy. J Urol. 1998;160:2021-4.

13. Weijl NI, Rutten MF, Zwinderman AH, Keizer HJ, Nooy MA, Rosendaal FR, et al. Thromboembolic events during chemotherapy for germ cell cancer: a cohort study and review of the literature. J Clin Oncol. 2000;18:2169-78.

14. Moore RA, Adel N, Riedel E, Bhutani M, Feldman DR, Tabbara NE, et al. High incidence of thromboembolic events in patients treated with cisplatinbased chemotherapy: a large retrospective analysis. J Clin Oncol. 2011;29: 3466-73.

15. Zahir MN, Shaikh Q, Shabbir-Moosajee M, Jabbar AA. Incidence of venous Thromboembolism in cancer patients treated with Cisplatin based chemotherapy - a cohort study. BMC Cancer. 2017;17(1):57.

16. Seng S, Liu Z, Chiu SK, Proverbs-Singh T, Sonpavde G, Choueiri TK, et al. Risk of venous Thromboembolism in patients with cancer treated with Cisplatin: a systematic review and meta-analysis. J Clin Oncol. 2012;30:4416-26.

17. Khorana AA, Kuderer NM, Culakova E, Lyman GH, Francis CW. Development and validation of a predictive model for chemotherapy-associated thrombosis. Blood. 2008;111:4902-7.

18. Nuver J, Smit AJ, van der Meer J, van den Berg MP, van der Graaf WT, Meinardi MT, et al. Acute chemotherapy-induced cardiovascular changes in patients with testicular cancer. J Clin Oncol. 2005;23:9130-7.

19. Jafri M, Protheroe A. Cisplatin-associated thrombosis. Anti-Cancer Drugs. 2008;19:927-9.

20. Lechner D, Kollars M, Gleiss A, Kyrle PA, Weltermann A. Chemotherapyinduced thrombin generation via procoagulant endothelial microparticles is independent of tissue factor activity. J Thromb Haemost. 2007;5:24452452.

21. Fotopoulou C, duBois A, Karavas AN, Trappe R, Aminossadati B, Schmalfeldt B, Pfisterer J, et al. Incidence of venous thromboembolism in patients with ovarian cancer undergoing platinum/paclitaxel containing first-line chemotherapy: an exploratory analysis by the Arbeitsgemeinschaft Gynaekologische Onkologie ovarian cancer study group. J Clin Oncol. 2008; 26:2683-9.

22. Dieckmann KP, Gerl A, Witt J, Hartmann JT, German Testicular Cancer Study Group. Myocardial infarction and other major vascular events during chemotherapy for testicular cancer. Ann Oncol. 2010;21(8):1607-11.

23. Cohen AT, Katholing A, Rietbrock S, Bamber L, Martinez C. Epidemiology of first and recurrent venous thromboembolism in patients with active cancer. A population-based cohort study. Thromb Haemost. 2017;117:57-65.

24. Khorana AA, Francis CW, Culakova E, Fisher Rl, Kuderer NM, Lyman GH. Thromboembolism in hospitalized neutropenic cancer patients. J Clin Oncol. 2006;24:484-90

25. Lyman GH, Bohlke K, Khorana AA, Kuderer NM, Lee AY, Arcelus Jl, et al. Venous thromboembolism prophylaxis and treatment in patients with cancer: American Society of Clinical Oncology clinical practice guideline update 2014. J Clin Oncol. 2015;33(6):654-6.

26. NCCN guidelines (Cancer-associated venous thromboembolic disease) Available at: https://www.nccn.org/professionals/physician_gls/pdf/vte.pdf. Accessed on 02 April 2017.

27. Abdel-Razeq H, Albadainah F, Hijjawi S, Mansour A, Treish I. Venous Thromboembolism (VTE) in hospitalized cancer patients: prophylaxis failure or failure to Prophylax. J Thromb Thrombolysis. 2011;3:107-12.

28. Abdel-Razeq H, Mansour A, Saadeh SS, Abu-Nasser M, Makoseh M, Salam M, et al. The application of current proposed venous Thromboembolism risk assessment model for ambulatory patients with cancer. Clin Appl Thromb Hemost. 2017:1076029617692880. https://doi.org/10.1177/ 1076029617692880

29. Barni S, Labianca R, Agnelli G, Bonizzoni E, Verso M, Mandalà M, et al. Chemotherapy-associated thromboembolic risk in cancer outpatients and effect of nadroparin thromboprophylaxis: results of a retrospective analysis of the PROTECHT study. J Transl Med. 2011;9:179.

30. Agnelli G, George DJ, Kakkar AK, Fisher W, Lassen MR, Mismetti P, et al. Semuloparin for thromboprophylaxis in patients receiving chemotherapy for cancer. N Engl J Med. 2012;366:601-9.
31. Maraveyas A, Waters J, Roy R, Fyfe D, Propper D, Lofts F, et al. Gemcitabine versus gemcitabine plus dalteparin thromboprophylaxis in pancreatic cancer. Eur J Cancer. 2012;48:1283-92.

32. Pelzer U, Opitz B, Deutschinoff G, Stauch M, Reitzig PC, Hahnfeld S, et al. Efficacy of prophylactic low-molecular weight heparin for ambulatory patients with advanced pancreatic cancer: outcomes from the CONKO-004 trial. J Clin Oncol. 2015;33:2028-34.

\section{Submit your next manuscript to BioMed Central and we will help you at every step:}

- We accept pre-submission inquiries

- Our selector tool helps you to find the most relevant journal

- We provide round the clock customer support

- Convenient online submission

- Thorough peer review

- Inclusion in PubMed and all major indexing services

- Maximum visibility for your research

Submit your manuscript at www.biomedcentral.com/submit
) Biomed Central 